\title{
Survei Kemampuan Keterampilan Teknik Dasar Permainan Bolabasket Pemain Putra Junior Kabupaten Ponorogo Tahun 2020
}

\author{
Siti Nurrochmah, Erwin Achmad Yusuf* \\ Universitas Negeri Malang, Jl. Semarang No. 5 Malang, Jawa Timur, Indonesia \\ *Penulis korespondensi, Surel: erwinahmady@gmail.com
}

Paper received: 17-6-2021; revised: 1-7-2021; accepted: 8-7-2021

\begin{abstract}
The purpose of this study was to determine the ability of the basic technical skill to play basketball which is owned by junior male players in Ponorogo Regency. This study used a quantitative descriptive survey design. The subjects of this study were 30 male junior players in Ponorogo Regency. Data collecting was carried out using the measurement technique of the basic technical skill test form of basketball playing. The results of data analysis included (1) the basic technical skill of passing chest pass were in the medium category or (good enough) with a percentage of 40 percent, (2) the basic technical skills of dribble zig-zag are in the medium category or (good enough) with a percentage of 36,67 percent, (3) the basic technical skills of under basket shooting are in the medium category or (good enough) with a percentage of 43.33 percent. it can be concluded that the ability of basic technical skills to play basketball for junior men in Ponorogo Regency in 2020 on average has a high percentage in the medium category (quite good). Researchers suggest to the trainer that in compiling an exercise program in addition to physical training also exercise basic technical skills included in a routine training program.
\end{abstract}

Keywords: basic technical skills; basketball; junior player

\begin{abstract}
Abstrak
Tujuan dari penelitian ini dilakukan adalah untuk mengetahui kemampuan keterampilan teknik dasar bermain bolabasket yang dimiliki oleh pemain putra junior Kabupaten Ponorogo. Penelitian ini menggunakan rancangan survei bentuk deskriptif kuantitatif. Subjek penelitian ini adalah pemain putra junior Kabupaten Ponorogo berjumlah 30 orang. Pengumpulan data dilakukan dengan menggunakan teknik pengukuran bentuk tes keterampilan teknik dasar permainan bolabasket. Hasil analisis data antara lain (1) keterampilan teknik dasar passing chest pass berada pada kategori sedang (cukup baik) dengan persentase 40 persen, (2) keterampilan teknik dasar dribble zig-zag berada pada kategori sedang (cukup baik) dengan persentase 36,67 persen, (3) keterampilan teknik dasar shooting under basket berada pada kategori sedang (cukup baik) dengan persentase 43,33 persen. dapat disimpulkan bahwa kemampuan keterampilan teknik dasar permainan bolabasket putra junior Kabupaten Ponorogo pada tahun 2020 rata-rata memiliki persentase tinggi pada kategori sedang (cukup baik). Peneliti menyarankan kepada pelatih agar dalam menyusun program latihan selain latihan fisik juga latihan keterampilan teknik dasar dimasukan dalam program latihan rutin.
\end{abstract}

Kata kunci: keterampilan teknik dasar; bolabasket; pemain junior

\section{Pendahuluan}

Olahraga merupakan salah satu kebutuhan hidup yang harus dipenuhi oleh setiap manusia, tidak hanya untuk membuat tubuh menjadi sehat, dengan olahraga secara teratur akan membuat hidup menjadi lebih segar dan bugar dalam menjalankan aktivitas sehari-hari. Menurut Santoso (2013) Olahraga merupakan serangkaian gerak raga yang teratur dan terencana untuk memelihara fungsi tubuh, yang berarti mempertahankan hidup dan 
meningkatkan kualitas hidup. Hal ini sependapat dengan Azhar (2018) bahwa Olahraga adalah suatu usaha untuk membina raga, mengembangkan tubuh agar sehat, kuat dan produktif. Berdasarkan tujuan utama olahraga bukan saja pembangunan fisik melainkan juga pembangunan mental dan spiritual (Wiarto, 2015). Olahraga dapat dilakukan oleh siapa saja mulai dari anak-anak dewasa, maupun lansia. Sebab dengan berolahraga banyak manfaat yang dapat kita rasakan, sehingga kita akan terhindar dari berbagai macam-macam penyakit yang bisa saja menyerang kita sewaktu-waktu. Aktivitas fisik akan menimbulkan dampak positif dalam hal kebugaran apabila dilakukan dan dikelola secara teratur, terencana dan tepat. Dari pendapat para ahli dapat disimpulkan bahwa olahraga memiliki manfaat dan tujuan yang sangat luas, olahraga merupakan suatu bentuk latihan yang dilakukan secara sistematis untuk mendapatkan kualitas dalam kebugaran serta mengembangkan kemampuan fisik yang ada pada tubuh manusia dengan cara menggerakkan tubuh sesuai dengan fungsinya. Olahraga menurut jenisnya dibagi menjadi dua macam yaitu olahraga modern dan olahraga tradisional. Olahraga modern adalah olahraga yang dimodifikasi dan menyesuaikan dengan kebutuhan masyarakat saat ini, sedangkan olahraga tradisional adalah olahraga yang cenderung mengarah pada permainan tradisional ke daerah untuk olahraga modern terdapat banyak olahraga yang dipermainkan seperti halnya olahraga permainan bola kecil dan besar. Permainan olahraga bola besar meliputi bolabasket, bolavoli, sepakbola dan lain-lain, sedangkan permainan bola kecil meliputi bulutangkis, tenis meja, tenis lapangan dll.

Cabang olahraga bolabasket merupakan suatu cabang olahraga yang didalamnya memiliki unsur kesenangan serta kerjasama tim untuk mendapatkan poin kemenangan. Permainan ini termasuk dalam katagori permainan yang kompleks dalam gerakanya, terdiri dari gabungan unsur-unsur gerak yang terkoordinir dengan rapi, sehingga dapat bermain dengan baik. Menurut Bambang \& Lukmanul (2015) bolabasket adalah suatu permainan yang dimainkan oleh dua regu terdiri dari 5 orang pemain dan jenis permainan ini bertujuan untuk mencari nilai atau angka sebanyak-banyaknya. Menguasai keterampilan teknik dasar menjadi sebuah modal yang utama untuk memudahkan dalam setiap permainan atau pertandingan Suatu keterampilan dalam permainan bola basket akan tercapai apabila dapat menguasai teknik dasar dengan baik dan benar. Setiap pemain bolabasket diharuskan memiliki keterampilan yang baik dalam mengolah bola agar mampu bekerjasama dengan baik antara pemain satu tim. Keterampilan dapat didefinisikan sebagai aktivitas gerak atau gerakangerakan yang mendasar dalam olahraga yang dilakukan secara efektif dan efisien serta harus dipelajari agar mendapatkan bentuk yang benar. Teknik adalah suatu proses gerakan atau pembuktian dalam praktek dengan sebaik mungkin untuk menyelesaikan tugas yang pasti dalam cabang olahraga disusun atas dasar anatomi/fisiologis, mekanik,biomekanika dan mental (Hidayat, 2014). Dapat disimpulkan bahwa keterampilan teknik dasar adalah kemampuan atau skill dalam melakukan sebuah gerakan-gerakan mendasar dengan sebaik mungkin agar dapat bermain bolabasket dengan cara yang benar dan efektif. Keterampilan dasar yang perlu dilatih bagi pemula Sumaryoto \& Nopembri (2017) Dalam teknik dasar bola basket terdapat 3 jenis yang harus dipelajari atau dikuasai diantaranya adalah (passing) mengumpan, (shooting) yang artinya menembak kering/keranjang, dan (dribble) menggiring atau bergerak dengan bola. teknik yang sering digunakan dalam permainan bolabasket yang sering dijumpai dalam pertandingan adalah passing setinggi dada, pantul, diatas kepala dan passing satu tangan, dribble jenis crossover, dan shooting menggunakan lompatan jump stop serta lay up. 
Cabang olahraga ini memerlukan kualitas yang dapat dicapai melalui latihan terus menerus, sistematis dan terorganisasi dengan baik agar bisa mencapai tingkat prestasi yang maksimal. Kemampuan menguasai teknik dasar sangat penting untuk dimiliki oleh seorang pemain yang berguna dalam mengembangkan permainanya, sehingga tidak mengalami kesulitan untuk menerima materi latihan selanjutnya. Harsono (2015) Berpendapat bahwa peran pelatih sangatlah penting untuk membina dan melakukan pelatihan pada setiap atletnya, oleh karena itu tanpa bimbingan dan pengawasan dari seorang pelatih, prestasi yang tinggi akan sukar dicapai.Hal ini sesuai dengan hasil penelitian yang dilakukan oleh Afifudin (2013) tentang pembinaan bolabasket di klub bintang muda Jepara mendapatkan hasil dalam kategori kurang. hal ini dapat dilihat dari aspek pelatih dan juga pengurus yang kurang intensif melakukan pengamatan serta pemantauan perkembangan atlet. Pentingnya pengawasan dan pendekatan sangat diperlukan. Penelitian yang dilakukan oleh Utomo (2016) mengenai pengaruh pemberian motivasi ekstrinsik reward ternyata memberikan pengaruh yang signifikan terhadap peningkatan hasil belajar shooting bola basket pada siswa kelas XI SMA Negeri 1 soko di Kabupaten Tuban. Untuk dapat menjadi pemain yang profesional tentunya harus diimbangi dengan latihan yang terencana dan pembinaan pemain secara mendasar. Menjadi pemain yang profesional atau kreatif diperlukan mengakumulasi waktu latihan lebih banyak diluar jadwal latihan dan pengalaman yang banyak.

Pembinaan sejak dini dan melakukan program latihan sesuai dengan porsi atau batasan umurnya merupakan langkah yang tepat untuk mengembangkan sebuah keterampilan di setiap cabang olahraga, terutama cabang bolabasket. Kegiatan tersebut dimaksudkan untuk memunculkan bibit-bibit baru dimasa yang akan datang. Dikalangan masyarakat terutama pada ranah instansi pendidikan jenjang SMP, SMA dan Mahasiswa, olahraga permainan bolabasket semakin banyak digemari dan mengalami perkembangan yang sangat pesat, itu dapat terlihat dari adanya lapangan-lapangan yang ada di setiap sekolah maupun Perguruan Tinggi Negeri/Swasta walaupun ada yang tidak sesuai dengan standarnya. Hal ini juga terbukti dengan adanya klub-klub yang ada di Indonesia dan atlet bolabasket pelajar serta adanya pertandingan yang sering diselenggarakan seperti turnamen-turnamen antarklub, event pelajar dari tingkat daerah hingga nasional. Tim permainan bolabasket yang mewakili Indonesia pada Sea Games 2019 yang diselenggarakan di Manila Filipina, belum mencapai target yang diharapkan yaitu medali emas. Hal tersebut dapat dilihat dalam pencapaian medali tim bolabasket yang memperoleh medali perunggu. Bersaing dengan negara-negara lainya seperti Filipina dan Thailand merupakan lawan terkuat yang dihadapi oleh tim bolabasket Indonesia. Adapun dugaan mengenai penyebab gagalnya tim bolabasket Indonesia untuk mencapai target medali emas adalah faktor kesiapan dalam pembentukan tim, program latihan yang digunakan, Strategi yang diterapkan oleh seorang pelatih, kurangnya kerjasama dalam tim, dan turnover atau seorang pemain sering kehilangan penguasaan bola dalam pertandingan.

Perkembangan dan kemajuan bolabasket di Jawa Timur banyak diisi dari tim-tim sekolah, walaupun peran klub luar sekolah juga cukup besar dalam melahirkan pemain yang berkualitas dan berbakat Akan tetapi eksistensi tim sekolah dalam membina siswanya ternyata mampu memberikan sumbangan yang cukup besar untuk memajukan cabang olahraga ini. Kota Malang yang terkenal dengan sebutan kota pelajar, basket merupakan olahraga yang populer sehingga setiap tahunnya terdapat event-event yang silih bergantian adanya. Perkembangan di seluruh Kabupaten di Jawa Timur masih belum sebanyak di kota besar seperti halnya kota Malang, ini dapat dilihat dari event setiap tahunnya terdapat kurang lebih 
20 event, dimulai dari Dispora Cup, Kejurkot, FBL FIK UM, DBL, MBL, LIMA, IMANOKE CUP, LA Campus League, Machung star Battle, EST, FK UB, ITN CUP, POLINEMA CUP, FTP, FKG se Indonesia dan masih banyak lainya. Hal tersebut berbanding jauh dengan Kabupaten Ponorogo memiliki event resmi yang diadakan oleh PERBASI dalam setahun sekali dan hanya antar SMP. Untuk event yang tidak resmi terdapat satu instansi yang mengadakan pertandingan bola basket dalam agenda setiap tahunya antar SMP dan SMA Se-Karisidenan Madiun. Sedangkan untuk klub masih aktif mengikuti kejuaran daerah berdasarkan batasan umur.

Beberapa sekolah di Kabupaten Ponorogo yang memiliki komitmen tinggi untuk mendukung siswanya berprestasi dibidang olahraga ini diantaranya adalah SD Katolik Santa Maria, SMP Negeri 1, 2, dan 6 Ponorogo, SMP Babadan 1 dan 2, sedangkan untuk SMA dan SMK terdapat 3 sekolah yaitu SMAN 1 dan 2, SMK Jenengan Serta SMK PGRI 2 Ponorogo. Sekolah tersebut aktif dalam mengikuti pertandingan luar daerah terutama tingkat karesidenan yang diselenggarakan disekolah-sekolah resmi maupun tidak resmi. Dari dukungan tim-tim basket dari sekolah tersebut tentunya Ponorogo tidak pernah habis dalam hal stok pemain potensial, dapat dilihat dari sekolah dasar sampai tingkat sekolah menengah atas potensi diperkirakan akan terus bermunculan dan berkembang.

Pada tahun 2014-2019 tim bolabasket yang ada di Kabupaten Ponorogo selalu ikut serta dalam kejuaran daerah, adapun prestasinya adalah ketika mendapatkan peringkat 3 KEJURDA JATIM tahun 2014 dan meloloskan tim basket putra pada Pra PORPROV JATIM 2015. Selain itu, dari mengikuti kompetisi secara rutin dapat terlihat dari terpilihnya salah satu pemain untuk mengikuti dan bergabung pada timnas Indonesia bolabasket $U$-18 untuk pertandingan FIBA 3 on 3 world championship pada tahun 2016. Buah dari hasil prestasi tersebut membawa dampak yang baik bagi PERBASI Kabupaten Ponorogo, sehingga dapat memberanikan diri untuk mengikutsertakan tim cabang bolabasket pada PORPROV JATIM yang diselenggarakan di Kota Banyuwangi Pada tahun 2015. Namun pada 2016 hingga 2020 klub dan tim basket sekolah yang ada di Kabupaten Ponorogo tidak menorehkan prestasi yang gemilang, ini terlihat dari kompetisi bolabasket se-karesidenan Madiun yang diadakan di GOR SINGODIMEDJO Ponorogo bahwa hasil dalam kompetisi tersebut perolehan juara masih didominasi oleh tim sekolah dari luar Kabupaten Ponorogo dan untuk klub selalu gagal meraih juara dalam kejuaran daerah. Sehingga berdampak pada PERBASI Ponorogo yang tidak bisa ikut adil dalam ajang PORPROV JATIM VI yang diselenggarakan di Kabupaten Gresik, Lamongan dan Tuban pada tahun 2019.

Berdasarkan hasil observasi peneliti pada pelatih-pelatih yang ada di Ponorogo terutama pada pelatih bolabasket Sahabat memberikan informasi bahwa tingkat penguasaan keterampilan teknik dasar bolabasket belum semua pemain menguasai secara maksimal, latihan dilakukan dalam satu minggu sebanyak empat kali yaitu pada hari selasa, kamis, sabtu, dan minggu. Pelatih juga belum memiliki data hasil tes dan pengukuran mengenai kemampuan keterampilan teknik dasar pemainya dan hanya berdasarkan pengamatan semata saja. Pelatih tersebut juga belum memiliki lisensi kepelatihan bolabasket, akan tetapi memiliki pengalaman sebagai pemain bolabasket ABL dari salah satu klub yang ada di Kota Surabaya. Oleh karena itu, dari hasil temuan studi pendahuluan pentingnya dilakukan tes dan pengukuran yang berguna mendapatkan informasi berupa data mengenai perkembangan penguasaan dan keahlian keterampilan teknik dasar pemain dianggap sangat penting. Hal ini penting dilakukan suatu kajian terkait perkembangan melalui pengukuran berupa tes yang diadakan melalui penelitian terhadap keterampilan teknik dasar pada pemain. Hasil penelitian terdahulu yang 
dilakukan Devita (2013) tentang keterampilan teknik dasar tim bolabasket putra kelompok umur 18 tahun klub sahabat tahun 2012 mendapatkan hasil termasuk dalam kategori sedang.

Bertolak pada uraian masalah hal terdahulu dan studi awal yang dilakukan oleh peneliti dan berpijak pada hasil studi pada penelitian sebelumnya, maka permasalahan tentang keterampilan teknik dasar bolabasket menarik untuk diteliti. Karena yang menjadi latar belakang masalah ini adalah tentang keterampilan teknik dasar yang belum diketahui seberapa baik atau tidaknya kemampuan seluruh pemain. Pemain belum pernah dites dan diukur sehingga berdampak pada prestasi yang menurun dari setiap tahun, maka peneliti mengkaji masalah tersebut melalui penelitian berjudul "Survei Kemampuan Keterampilan Teknik Dasar Permainan Bolabasket Pemain Putra Junior Kabupaten Ponorogo Tahun 2020”.

\section{Metode}

Penelitian ini menggunakan rancangan survei bentuk deskriptif. Penelitian deskriptif kuantitatif ini bertujuan untuk mendeskripsikan atau memberikan gambaran terhadap objek yang diteliti melalui data dan sampel atau populasi sebagaimana adanya. Tempat yang digunakan dalam penelitian ini adalah lapangan klub Sahabat Kabupaten Ponorogo. Subjek dalam penelitian ini adalah pemain putra junior Kabupaten Ponorogo berjumlah 30 orang. Teknik untuk memperoleh data pada penelitian ini menggunakan pengukuran bentuk tes. instrumen tes yang digunakan adalah tes keterampilan teknik dasar bolabasket yang meliputi tes teknik dasar passing menggunakan tes passing chest pass (lempar tangkap ke dinding selama 30 detik), teknik dasar shooting menggunakan tes shooting under basket 30 detik, dan teknik dasar dribble menggunakan teknik dribble zigzag. Sedangkan untuk instrumen non-tes yang digunakan dalam penelitian ini yaitu berupa observasi (pengamatan) unjuk kerja pelaksanaan setiap tes yang dilaksanakan.

Berdasarkan tujuan penelitian dan pertimbangan jenis data yang diperoleh dari tes keterampilan yang meliputi passing, shooting dan dribble, menggunakan alat-alat terstandar misalnya stopwatch dan midline dengan data yang terkumpul berupa jenis data rasio, maka teknik analisis data yang digunakan untuk mengungkap tentang keterampilan teknik dasar permainan bolabasket pemain putra junior Kabupaten Ponorogo adalah statistika deskriptif kuantitatif. Teknik analisis statistika deskriptif kuantitatif yang digunakan berupa tendensi sentral bentuk ukuran mean, modus, median dan teknik variabilita bentuk ukuran standar deviasi sampel, variansi (penyebaran data) sampel dan koefisien variansi.

\section{Hasil dan Pembahasan}

\subsection{Hasil}

Tabel 1. Penyajian Hasil Analisis Data Hasil Tes Kemampuan Keterampilan Teknik Dasar Permainan Bolabasket Pemain Putra Junior Kabupaten Ponorogo Tahun 2020

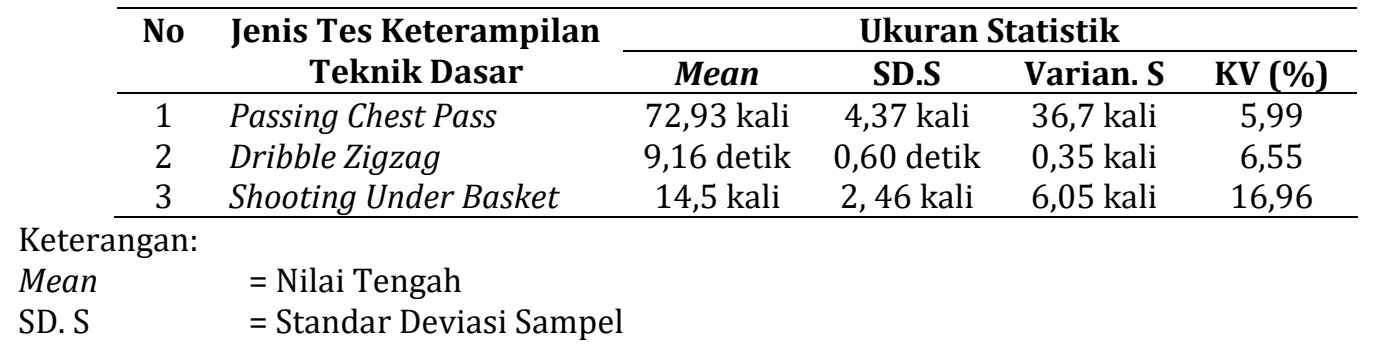


Varian. $S \quad=$ Varian Sampel

$\mathrm{KV} \quad=$ Koefisien Variansi

Berdasarkan sajian hasil analisis data yang disajikan pada Tabel 4.2 dari hasil tes keterampilan passing chest pass, shooting under basket dan dribble zigzag untuk pemain putra junior Kabupaten Ponorogo yang berjumlah 30 pemain maka diperoleh hasil tes keterampilan (passing chest pass) dengan hasil nilai mean 72,93 kali, nilai standar deviasi 4,37 kali, varian sampel 36,7 kali dan koefisien variansi 5,99\%. Untuk tes keterampilan (shooting under basket) dengan hasil nilai mean 14,5 kali, nilai standar deviasi 2,46 kali, varian sampel 6,05 kali dan koefisien variansi $16,96 \%$. Sedangkan tes keterampilan (dribble zigzag) dengan hasil nilai mean 9,16 detik, nilai standar deviasi 0,60 detik, varian sampel 0,35 detik dan koefisien variansi 6,55\%. Dari hasil koefisien variansi seluruh butir tes keterampilan teknik dasar permainan bolabasket putra junior Kabupaten Ponorogo keterampilan passing chest pass diperoleh hasil analisis KV 5,99\% dan keterampilan dribble diperoleh hasil analisis KV 6,55 \% menunjukan lebih memusat dibandingkan butir tes lainya, artinya tes keterampilan teknik dasar passing chest pass dan dribble banyak pemain yang mempunyai skor baik sama antar individu. Sedangkan hasil tes keterampilan teknik dasar shooting under basket koefisien variansi diperoleh persentase 16,69\%, dapat disimpulkan bahwa tes shooting under basket lebih menyebar atau beragam artinya pada tes tersebut antar pemain memperoleh nilai yang sangat bervariasi. Dibawah ini disajikan tabel norma khusus dari keterampilan teknik dasar permainan bolabasket sebagai bentuk nilai norma untuk mengukur kemampuan keterampilan teknik dasar permainan bolabasket putra junior Kabupaten Ponorogo tahun 2020.

\subsubsection{Hasil Tes Keterampilan Passing Chest Pass}

Tabel 2. Klasifikasi Data Hasil Tes Keterampilan Passing Chest Pass

\begin{tabular}{ccccc}
\hline Skor interval & frekuensi & Frekuensi relatif & Kriteria & Jumlah kriteria \\
\hline$\geq 79$ & 4 & 13,33 & Baik sekali & \multirow{2}{*}{11} \\
$75-78$ & 7 & 23,33 & Baik & \\
$70-74$ & 12 & 40 & Cukup baik & \\
$66-69$ & 5 & 16,67 & Kurang baik & 19 \\
$\leq 65$ & 2 & 6,66 & Tidak baik & \\
\hline
\end{tabular}

Perolehan hasil pada kriteria baik sekali 4 pemain $(13,33 \%)$ dari 30 pemain. Terdapat 7 pemain $(23,33 \%)$ dari 30 pemain dalam kriteria baik. 12 pemain $(40 \%)$ dari 30 pemain dalam kriteria sedang (cukup baik), 5 pemain $(16,67 \%)$ dari 30 pemain dalam kriteria kurang baik dan terdapat 2 pemain $(6,66 \%)$ dari 30 pemain dalam kriteria tidak baik. Untuk hasil mean yaitu 72,93 kali, SD 4,37 kali, Varian 36,7 kali dan KV 5,99\%. Hasil analisis deskriptif tes kemampuan dan keterampilan teknik dasar permainan bolabasket passing chest pass pada pemain putra junior Kabupaten Ponorogo selengkapnya akan disajikan dengan grafik yang berdasarkan hasil norma tersebut. 


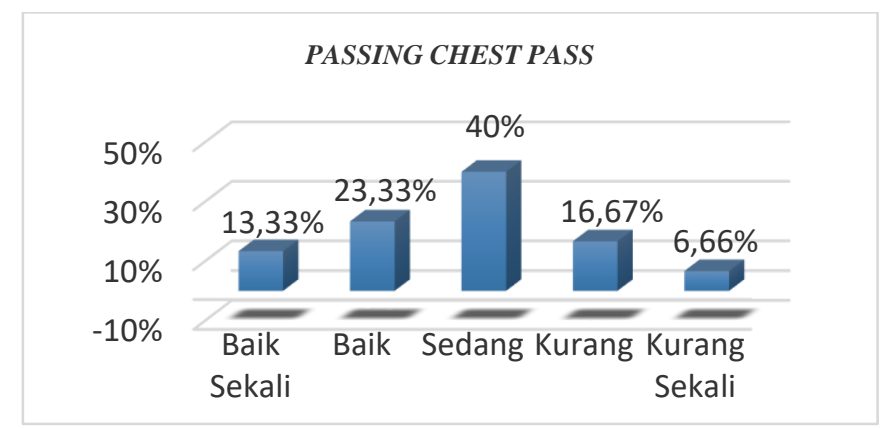

Gambar 1. Diagram Hasil Tes Passing Chest Pass

\subsubsection{Hasil Tes Keterampilan Dribble Zigzag}

Tabel 3. Klasifikasi Dat Hasil Tes Keterampilan Dribble Zigzag

\begin{tabular}{ccccc}
\hline Skor interval & frekuensi & Frekuensi relatif & kriteria & Jumlah kriteria \\
\hline$\geq 10,06$ & 1 & 3,33 & Tidak baik & \\
$9,46-10,05$ & 10 & 33,33 & Kurang baik & 22 \\
$8,86-9,45$ & 11 & 36,66 & Cukup baik & \\
$8,26-8,85$ & 5 & 16,67 & Baik & \multirow{2}{*}{8} \\
$\leq 8,25$ & 3 & 10 & Baik sekali & \\
\hline
\end{tabular}

Perolehan hasil pada kriteria baik sekali 3 pemain (10\%) dari 30 pemain, terdapat 5 pemain $(16,67 \%)$ dari 30 pemain dalam kriteria baik, 11 pemain $(36,67 \%)$ dari 30 pemain dalam kriteria sedang (cukup baik), 10 pemain $(33,33 \%$ ) dari 30 pemain dalam kriteria kurang baik dan 1 pemain $(3,33 \%)$ dari 30 pemain dalam kriteria tidak baik. Untuk hasil mean yaitu 9,16 detik, SD 0,60 detik, varian 0,35 detik, dan KV mendapatkan 6,55\%. Hasil analisis deskriptif tes kemampuan dan keterampilan teknik dasar permainan bolabasket dribble zigzag pada pemain putra junior Kabupaten Ponorogo selengkapnya akan disajikan dengan grafik yang berdasarkan hasil norma tersebut.

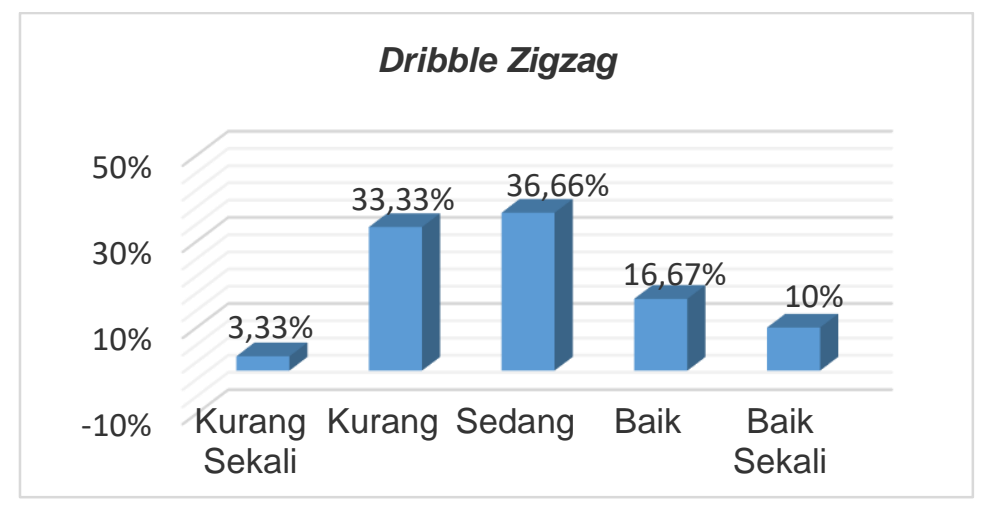

Gambar 2. Diagram Hasil Tes Dribble Zigzag 


\subsubsection{Hasil Tes Keterampilan Shooting Under Basket}

Tabel 4. Klasifikasi Data Hasil Tes Keterampilan Shooting Under Basket

\begin{tabular}{ccccc}
\hline Skor interval & Frekuensi & Frekuensi relatif \% & Kriteria & Jumlah kriteria \\
\hline$\geq 18$ & 4 & 13,33 & Baik sekali & 10 \\
$16-17$ & 6 & 20 & Baik & \\
$13-15$ & 13 & 43,33 & Cukup baik & \\
$11-12$ & 5 & 16,67 & Kurang & 20 \\
$\leq 10$ & 2 & 6,66 & baik & \\
\hline
\end{tabular}

Perolehan hasil pada kriteria baik sekali 4 pemain (13,33\%) dari 30 pemain, terdapat 6 pemain $(20 \%)$ dari 30 pemain dalam kriteria baik, 13 pemain $(43,33 \%)$ dari 30 pemain dalam kriteria sedang (cukup baik), 5 pemain $(16,67 \%)$ dari 30 pemain dalam kriteria kurang dan terdapat 2 pemain $(6,66 \%)$ dari 30 pemain dalam kriteria tidak baik. Untuk mean yaitu 14,5 kali, SD 2,46 kali, varian 6,05 kali sedangkan KV mendapatkan 16,96\%. Hasil analisis deskriptif tes kemampuan dan keterampilan teknik dasar permainan bolabasket dribble zig zag pada pemain putra junior Kabupaten Ponorogo selengkapnya akan disajikan dengan grafik yang berdasarkan hasil norma tersebut.

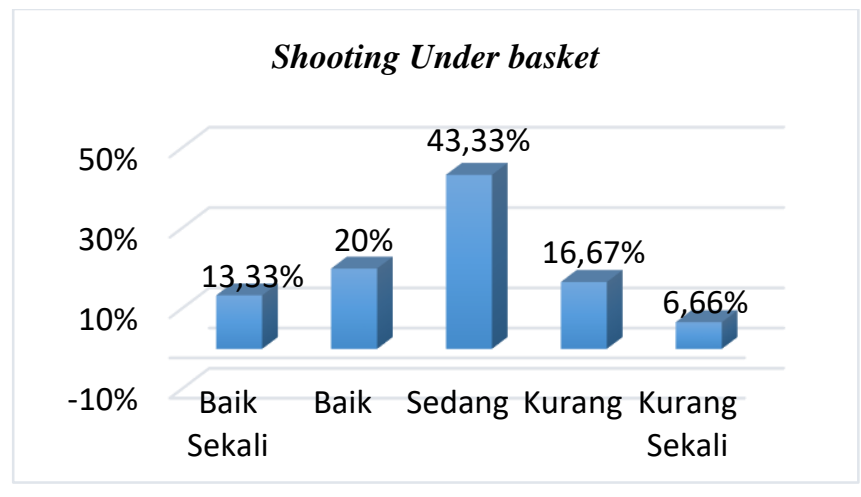

Gambar 3. Diagram Tes Shooting Under Basket

\subsection{Pembahasan}

Berdasarkan hasil analisis data, berikut akan disajikan pembahasan hasil penelitian yang merujuk pada rumusan masalah dan analisis data dari pemain bolabasket putra junior Kabupaten Ponorogo. Adapun pembahasan akan dimulai dari hasil analisis keterampilan teknik dasar passing, dribble dan shooting, Berikut dipaparkan pembahasan masing-masing hasil penelitian dari keterampilan teknik dasar yang diteliti.

\subsubsection{Keterampilan Teknik Dasar Passing Chest Pass 30 Detik Pada Dinding}

Secara keseluruhan berdasarkan hasil analisis data tes keterampilan teknik dasar permainan bolabasket tes passing chest pass 30 detik pada pemain putra junior Kabupaten Ponorogo yang diikuti 30 pemain diperoleh hasil pada kriteria baik sekali dan baik berjumlah 11 pemain (36,66\%) dari 30 pemain. Berjumlah 19 pemain $(63,33 \%)$ dari 30 pemain berada pada kriteria di bawah baik antara kriteria kurang baik sampai cukup baik. Berarti hasil tes keterampilan teknik dasar passing dominan berada pada kategori (di bawah baik atau tidak 
baik). Sesuai dengan hasil tes komponen keterampilan teknik dasar passing chest pass yang dominan berada pada di bawah baik atau kriteria tidak baik, hal tersebut berbanding terbalik dengan penelitian penelitian yang dilakukan oleh Auliya (2018) yang menjelaskan bahwa hasil penelitian pada pemain CLS junior Kelompok usia 16 tahun dalam hal passing yaitu dalam kategori sedang. Padahal untuk menjadi pemain dituntut untuk bisa melakukan passing dengan tepat dan akurat karena passing adalah salah satu kunci keberhasilan serangan sebuah tim dan sebuah unsur penentu tembakan-tembakan yang berpeluang besar mencetak angka. Ini sesuai dengan pendapat Yolis, (2018) bahwa passing atau mengumpan merupakan cara paling efektif dalam menggerakan bola dari satu bagian lapangan permainan sendiri ke bagian depan daerah lawan dan salah satu teknik dasar permainan bolabasket yang wajib dikuasai oleh seorang pemain.

Passing jenis chest pass merupakan teknik yang paling sering kita jumpai dalam bermain bolabasket. Hal ini diperkuat dari pernyataan Fekum (2011) bahwa teknik passing chest pass merupakan teknik yang sering digunakan untuk mengumpan dalam olahraga bolabasket. Komponen keterampilan teknik dasar passing chest pass dapat meningkat kualitasnya, maka peserta seharusnya melakukan latihan-latihan yang lebih giat lagi, bervariasi dan mengacu pada prinsip latihan yang telah diberikan oleh seorang pelatih. Adapun macam-macam variasi latihan untuk keterampilan teknik dasar passing chest pass adalah operan segitiga, operan segi empat setelah passing kemudian lari untuk feedback, operan lari menyilang yang artinya setelah mengumpan pemain lari menuju belakang kelompok yang di passing dan operan melingkar. Sedangkan menurut Amber (2016) latihan passing dapat menggunakan cara mengoperkan bola secara silang, kucing di tengah lingkaran, mengoperkan bola dalam tim yang artinya permainan dilakukan dengan membentuk sebuah tim serang dan bertahan, pada latihan bentuk ini bola tidak boleh di dribble serta tidak boleh dipegang selama 5 detik yang terakhir perlombaan mengoper bola pada media dinding. Selain itu variasi latihan passing chest pass menurut Sumaryoto \& Nopembri (2017) dapat dilakukan dengan mengoper bola dalam bentuk bermain. Adapun variasi lainnya dapat menggunakan passing berpasangan bisa dengan duduk atau berdiri, passing 3 orang dari backcourt ke front court.

Terkait dengan kegiatan latihan yang menyenangkan melalui upaya merancang bentuk latihan yang bervariasi terdapat hasil penelitian terdahulu yang dapat meningkatkan keterampilan teknik dasar passing chest pass seperti penelitian yang dilakukan oleh Setya (2014) mengenai penerapan model pembelajaran drill dan practice terhadap belajar chest pass pada permainan bolabasket ada pengaruh yang signifikan berdasarkan analisis data dapat diketahui sebesar 45,45\%. Sedangkan penelitian dari Sari (2019) mengemukakan bahwa, untuk meningkatkan kemampuan passing bolabasket dapat dilakukan dengan cara membuat variasi latihan dengan four corner drill dan five player star drill. Selain itu penelitian yang dilakukan Nuswantoro \& Supriyadi (2019) menyimpulkan bahwa latihan menggunakan metode permainan dapat meningkatkan kemampuan passing bolabasket.

Penelitian yang dilakukan oleh Budianti (2018) bahwa latihan passing melalui video visual dapat membantu untuk mempermudah dan mempercepat anggota dalam memahami serta menguasai teknik passing. Selain itu penelitian yang dilakukan Risyal (2018) Risyal mengenai pelatihan menggunakan metode tutor sebaya dapat memberikan pengaruh signifikan terhadap hasil belajar passing chest pass. Berdasarkan hasil analisa di lapangan peneliti menemukan penyebab kurangnya hasil kemampuan teknik dasar passing chest pass disebabkan karena latihan teknik yang kurang optimal. Penelitian yang dilakukan oleh Aryana 
(2013) menyimpulkan bahwa pelatihan push-up berpengaruh terhadap peningkatan kekuatan menarik dan mendorong otot lengan. Dari hasil penelitian tersebut unsur daya ledak otot lengan sangatlah penting dan dibutuhkan dalam unjuk kerja passing. Agar daya ledak mampu memberikan kontribusi terhadap passing maka dapat melakukan latihan berupa (a. latihan otot lengan seperti lempar bola medicine) dan (b. kecepatan melempar bola basket). Latihan tersebut sejalan dengan penelitian yang dilakukan Rusyda, Nurrochmah \& Heynoek (2016) terdapat peningkatan kemampuan daya ledak otot lengan akibat latihan lempar bolabasket pull-chest pass lebih baik dibandingkan dengan lempar bolabasket duduk di lantai bersandar. Penelitian yang sama dari Khoirina (2017) bahwa ada pengaruh latihan lempar bolabasket berdiri dan duduk bersandar di tembok terhadap kemampuan daya ledak otot lengan.

\subsubsection{Keterampilan Teknik Dasar Dribble Zigzag}

Berdasarkan hasil analisis data tes keterampilan teknik dasar dribble permainan bolabasket pemain putra junior Kabupaten Ponorogo yang diikuti 30 pemain diperoleh hasil berjumlah 8 pemain $(26,66 \%)$ dari 30 pemain pada kriteria baik dan baik sekali. Kriteria di bawah baik yaitu antara kriteria tidak baik sampai dengan sedang (cukup baik) berjumlah 22 pemain $(73,33 \%)$ dari 30 pemain. Berarti hasil tes teknik dasar dribble zig-zag dominan berada pada kategori tidak baik. Sesuai dengan hasil tes komponen keterampilan teknik dasar dribble zig-zag yang dominan berada pada kriteria tidak baik, Hal ini berbanding terbalik dengan penelitian yang dilakukan oleh Devita (2013) terhadap tim bolabasket putra kelompok umur 18 tahun klub sahabat Semarang mengenai keterampilan teknik dasar bolabasket dalam hal passing dominan berada dalam kategori sedang.

Padahal dribble adalah salah satu cara membawa bola dan juga dapat membantu memindahkan bola di lapangan serta menjauhkan diri dari penjagaan. Dribble merupakan cara untuk melindungi dan membawa bola ke arah depan pada daerah lawan. hal itu sesuai dengan pernyataan dari Khoeron (2017) bahwa dribble merupakan suatu cara menggiring bola untuk menghindari lawan sampai mencetak poin. Selain itu pernyataan dari Yolis (2018) dribble dapat juga dilakukan ditempat, yang berguna untuk mencari peluang sehingga dapat menerobos ke daerah pertahanan lawan, dan untuk mengacaukan pertahanan lawan serta permainan lawan menjadi tidak berkembang sehingga permainan menjadi terhambat. Untuk itu agar komponen keterampilan teknik dasar dribble zig-zag dapat lebih meningkat performa atau kualitasnya, maka seorang pemain harus lebih rajin dalam mengikuti latihan-latihan yang diprogramkan oleh pelatih. Adapun macam-macam variasi latihan yang dapat digunakan untuk keterampilan teknik dasar dribble adalah sebagai berikut.

Variasi Latihan meningkatkan kemampuan keterampilan teknik dasar dribble menurut Amber (2016) melakukan dribble bebas kemanapun arahnya dalam lingkup lapangan permainan selama waktu yang telah ditentukan atau menunggu aba-aba serta instruksi berhenti dari pelatih, latihan dengan kepala tegak atau bisa dengan mata tertutup baik memandang arah pelatih ataupun depan, menggunakan beberapa pemain untuk mengganggu yang bertujuan untuk berusaha melindungi bola dan meloloskan diri. Sedangkan menurut pendapat Wiradihardja (2017) latihan dribble dapat menggunakan tangan kanan dan kiri (dua bola) secara bersamaan dengan berlari ataupun berjalan, menggiring bola basket mengikuti teman yang ada di depannya dan tidak diperbolehkan bersinggungan dengan teman satu kelompok, menggiring cepat bola basket melalui rintangan (zig-zag) dalam bentuk larai berantai, berlomba mengambil bola secepat mungkin dan menggiring melalui rintangan yang 
telah ditentukan dalam bentuk lari berantai. Selain itu pernyataan dari Yolis (2018) latihan dribel membentuk angka delapan dengan posisi kaki (triple threat position) menghadap ke arah ring, dribel zig-zag, S-run dan Z-run, dribel cepat dari backcourt ke front court, dribel dua bola "latihan terbaik untuk memperbaiki penguasaan bola, dan dribel ditembok salah satu cara untuk menguatkan jari, pergelangan dan lengan).

Terkait dengan latihan terdapat hasil penelitian terdahulu tentang bentuk, variasi, dan metode latihan untuk meningkatkan kemampuan keterampilan teknik dasar dribble yang dilakukan oleh Anjasmaya (2016) menyimpulkan bahwa pelatihan speed dribble drill dan eight types of dribble berpengaruh terhadap keterampilan dribble. Sedangkan penelitian yang dilakukan Arif \& Supriyadi (2018) menyimpulkan bahwa latihan dengan menggunakan metode drill variasi dapat meningkatkan hasil prestasi dribble seorang pemain bolabasket. Selain itu penelitian Yusuf \& Wibowo (2017) bahwa model latihan dribble bolabasket efektif dapat meningkatkan hasil tes dribble bolabasket untuk atlet pemula club Garuda Bandung.

Latihan dribble memanglah menjenuhkan apabila tidak di imbangi dengan metode yang baik yang sesuai karakter pemain dan model latihan yang bervariasi, hal ini juga akan menghambat perkembangan seorang pemain. Adapun cara lainnya untuk dapat meningkatkan hasil belajar dapat menggunakan metode pendekatan, drill dan variasi latihan. Penelitian yang dilakukan Subhan (2013) terdapat peningkatan hasil belajar teknik dasar dribble bolabasket dengan pendekatan kontekstual teaching and learning. Cara lain dapat menggunakan permainan kecil seperti penelitian yang dilakukan Sriwahyuni (2014) ada pengaruh yang signifikan dari pengaruh permainan bola kecil terhadap hasil belajar gerak dasar dribble bolabasket di SMPN 1 Jatirego Tuban dengan persentase 22,26\%. Sedangkan penelitian Baqiyudin (2013) menyimpulkan bahwa pembelajaran menggunakan metode part practice memberikan dampak yang lebih baik terhadap hasil belajar dribble yaitu sebesar 22,63\%.

Melihat dari penelitian tersebut sejalan dengan penelitian yang dilakukan Erfani (2017) menunjukan bahwa dengan penerapan model pembelajaran model resiprokal dapat meningkatkan hasil belajar siswa yang signifikan pada materi dribble bolabasket pada siswa kelas X SMK Negeri 12 Surabaya. Sedangkan Penelitian dari Langga \& Supriyadi (2017) menyimpulkan bahwa model latihan menggunakan praktik distribusi memberikan pengaruh yang signifikan terhadap keterampilan dribble bolabasket anggota ekstrakurikuler bolabasket SMPN 18 Malang. Sedangkan penelitian yang dilakukan Ramadhan (2017) menyatakan bahwa metode part dapat meningkatkan hasil belajar dribble sebesar $25,28 \%$.

Berdasarkan pengamatan di lapangan peneliti menemukan penyebab kurangnya hasil kemampuan teknik dasar dribble adalah latihan fisik yang kurang optimal. Salah satunya adalah unsur kecepatan dan kelincahan. Padahal unsur tersebut sangat mempengaruhi dalam melakukan keterampilan menggiring bola dalam permainan bolabasket. Terkait hal itu sejalan dengan Penelitian yang dilakukan Aziz (2016) terdapat kontribusi positif faktor fisik dan teknik dalam mengoptimalkan kemampuan dribble atlet ekstrakurikuler bola basket tingkat SMA di Kabupaten Batang sebesar 94,5\%. Sedangkan penelitian yang dilakukan oleh Rustanto (2016) secara bersama-sama ada hubungan yang positif dan signifikan antara tinggi badan, kecepatan lari dan kelincahan dengan kemampuan dribbling pada permainan bolabasket kegiatan ekstrakurikuler SMPN 11 Pontianak. Selain itu penelitian yang dilakukan oleh Sya'bani \& Nurrochmah (2020) menyimpulkan bahwa latihan Z-Run dan S-Run dapat meningkatkan kelincahan peserta putra ekstrakurikuler bolabasket SMA Negeri 1 Lawang. 


\subsubsection{Keterampilan Teknik Dasar Shooting Under Basket 30 Detik}

Meninjau dari hasil analisis data tes keterampilan teknik dasar shooting permainan bolabasket pemain putra junior Kabupaten Ponorogo yang diikuti 30 pemain diperoleh hasil berjumlah 10 pemain $(33,33 \%)$ dari 30 pemain berada pada kriteria baik dan baik sekali. kriteria di bawah baik yaitu antara kriteria tidak baik sampai dengan sedang (cukup baik) berjumlah 20 pemain $(66,66 \%)$ dari 30 pemain. Berarti hasil tes teknik dasar shooting dominan berada pada kategori tidak baik.

Sesuai dengan hasil tes komponen keterampilan teknik dasar shooting under basket 30 detik yang berada pada kriteria tidak baik, hal tersebut berbanding terbalik dengan penelitian yang dilakukan oleh Nirwandi (2016) tentang keterampilan teknik dasar pada klub bolabasket putra sekolah menengah atas pembangunan laboratorium Universitas Negeri Padang dalam teknik shooting berada pada kategori kurang. Melihat dari hasil yang berada pada kriteria di bawah baik latihan teknik dasar shooting perlu untuk ditingkatkan dan dikembangkan melalui latihan yang tepat serta terprogram. Karena keterampilan terpenting dalam permainan bolabasket adalah kemampuan untuk shooting atau memasukan bola pada keranjang basket. Teknik memasukan bola merupakan pelengkap dari semua teknik yang diajarkan dalam olahraga bolabasket karena teknik ini dipergunakan untuk mencetak angka dengan memasukan bola ke basket atau ring untuk meraih sebuah kemenangan. Hal tersebut sesuai dengan pernyataan dari Amber (2016) bahwa shooting merupakan suatu keterampilan yang memberikan hasil nyata secara langsung, Selain itu memasukan bola ke dalam keranjang basket merupakan inti dari strategi permainan bolabasket. Sebuah tim tidak akan mencetak angka kemenangan kalau tidak berusaha menembak, karena menembak merupakan langkah terbaik untuk menang. Dari pendapat para ahli dapat disimpulkan bahwa shooting merupakan teknik yang dipergunakan untuk mendapatkan sebuah poin dan teknik ini merupakan pelengkap dari semua teknik yang diajarkan dalam permainan bolabasket. Seorang pemain tidak akan mendapatkan sebuah kemenangan jika tidak berani melakukan teknik memasukan bola (shooting).

Agar keterampilan teknik dasar shooting dapat meningkat kualitasnya, maka seorang pemain seharusnya melakukan latihan-latihan yang lebih intensif, terprogram dan berkelanjutan. Menerapkan prinsip latihan yang diberikan terhadap pelatih dirasa sangat penting agar tujuan latihan dapat tercapai sesuai dengan harapan. Adapun macam-macam variasi latihan untuk keterampilan teknik dasar shooting menurut Roji \& Yulianti (2014) latihan menembak dengan menggunakan satu tangan dengan melewati tali yang dilakukan secara berkelompok dan latihan menembak dari arah depan ring setelah bola lepas kemudian lari untuk rebound (menangkap kembali). Sedangkan menurut pendapat Wiradihardja (2017) latihan menembak dapat diawali dengan shooting menggunakan satu tangan, menembak bola basket dengan bergerak maju, mundur, menyamping yang dilakukan berpasangan atau berkelompok, shooting basket pada formasi berbanjar cara melakukannya adalah setelah melakukan tembakan kemudian lari ke arah belakang pada barisan di hadapannya dan melakukan latihan shooting berbanjar dari arah depan ring basket. Selain itu menurut Yolis (2018) Yolis Latihannya adalah sebagai berikut, Menembak jarak dekat sekitar 1 setengah meter - 2 meter, menembak dengan jarak yang semakin jauh, gerakan tipuan dengan sekali dribel posisi kaki (triple threat position) dan latihan tembakan cepat. 
Terkait dengan latihan terdapat hasil penelitian terdahulu tentang bentuk latihan yang dapat mempengaruhi serta meningkatkan keterampilan teknik dasar shooting pemain junior yang dilakukan oleh oleh Wicaksono (2014) mengenai latihan konsentrasi terhadap hasil shooting under basket (studi pada atlet putra klub bolabasket guardian Tuban) menyimpulkan bahwa konsentrasi memberikan kontribusi yang kuat terhadap hasil shooting under basket dan memberikan sumbangan sebesar 47\%. Hermanto (2017) bahwa konsep latihan menggunakan metode (balance, eye, elbow, follow through) terdapat pengaruh secara signifikan terhadap gerak dasar shooting dalam permainan bolabasket. Adapun cara latihan lainya seperti penelitian yang dilakukan oleh Afiansyah \& Januarto (2018) bahwa latihan titan shooting drill, elbow cutch and shooting drill dan 3 way shooting drill memberikan pengaruh terhadap peningkatan keterampilan dan akurasi shooting peserta ekstrakurikuler bolabasket putra SMP Laboratorium UM.

Agar mendapatkan hasil persentase kemampuan keterampilan teknik dasar shooting meningkat maka perlunya membuat metode yang tepat pada latihan dirasa sangat membantu. Terkait dengan metode tersebut terdapat penelitian terdahulu yang dilakukan oleh Majid \& Roesdiyanto (2018) menyimpulkan bahwa metode drill dapat meningkatkan dan memperbaiki hasil shooting. Selaras dengan penelitian Sartini \& Rusli (2019) bahwa pembelajaran dengan menggunakan metode drill dapat meningkatkan hasil belajar shooting permainan bolabasket pada siswa X MIA/ SMA Negeri 1 Raha. Sedangkan penelitian yang dilakukan oleh Auliya (2019) disimpulkan bahwa ada pengaruh yang signifikan kombinasi latihan drill dan visualimagery terhadap keterampilan shooting peserta ekstrakurikuler bolabasket SMP Negeri 1 Karangploso.

Pentingnya variasi dalam latihan sangat diperlukan berguna untuk membuat para pemain tidak merasakan jenuh dan dapat lebih berkembang lagi dalam situasi apapun. Penelitian yang dilakukan Yulidasari (2016) menyimpulkan bahwa variasi latihan shooting bolabasket pada kegiatan extrakulikuler di SMPN 22 Malang valid dan praktis digunakan. Produk yang dikemas dalam bentuk buku panduan dapat digunakan dengan mempelajari teknik yang benar untuk melakukan tembakan di dalam ruangan saat turun hujan. Pembuatan model latihan dirasa sangat penting, hal ini sesuai dengan penelitian yang dilakukan Raharjo \& Adi (2018) bahwa pemberian model latihan menembak berpengaruh terhadap peningkatan kemampuan jump shoot siswa anggota ekstrakurikuler SMAN 1 Tumpang. Sedangkan Penelitian yang dilakukan Adina (2018) menyimpulkan bahwa perlunya adanya sosialisasi dan coaching clinic agar pelatih dapat memperhatikan bagaimana cara melakukan jump shoot dengan benar.

Selain memperhatikan penggunaan model dan variasi latihan, faktor kondisi fisik juga sangat berperan dalam mempengaruhi hasil shooting seorang pemain. Contoh bentuk latihan, untuk daya ledak otot tungkai menurut Wiguna (2017) dapat menggunakan double ataupun single leg-vertical jump dan mountain run. untuk keseimbangan dapat menggunakan latihan sikap bangau (stork stand) sedangkan koordinasi dengan menggunakan lempar tangkap bola menggunakan tangan kiri dan kanan. Terkait hal tersebut terdapat penelitian tentang latihan yang dilakukan oleh Kusuma (2018) Kusuma bahwa latihan shooting run rinjani berbasis pada beban kaki (banding), rompi (backpack), pliometrik, kecepatan dan latihan teknik dasar shooting bolabasket dapat meningkatkan efektifitas under basket shoot pada tim bolabasket putra IKIP Mataram. Kontribusi daya ledak otot tungkai, koordinasi dan keseimbangan adalah hal yang selalu dibutuhkan serta saling berkaitan dalam melakukan teknik dasar shooting pada 
permainan bolabasket. Hasil penelitian yang dilakukan Apriansyah (2018) menyimpulkan bahwa terdapat hubungan yang signifikan antara koordinasi dan keseimbangan dengan hasil belajar gerakan shooting bola ke ring basket siswa/siswi SMP LKIA Pontianak. Sedangkan penelitian Aprianto \& Maidarman (2019) bahwa terdapat kontribusi daya ledak otot tungkai sebesar 36,37\% dan terdapat kontribusi keseimbangan sebesar 35,9\%, disimpulkan terdapat kontribusi daya ledak otot tungkai dan keseimbangan terhadap kemampuan jump shoot atlet bolabasket OGC Padang.

\section{Simpulan}

Berdasarkan tujuan penelitian yang telah disajikan dan merujuk pada pembahasan hasil penelitian secara keseluruhan dapat disimpulkan bahwa keterampilan teknik dasar passing chest pass, dribble zig-zag, shooting underbasket permainan bolabasket pemain putra junior Kabupaten Ponorogo tahun 2020 dominan memiliki persentase tinggi pada kemampuan kategori sedang (cukup baik).

\section{Daftar Rujukan}

Adina, F. dkk. (2018). Analisis Gerak Jump Shoot Terhadap Tingkat Keberhasilan Point di Tim Bola Basket Unit Kegiatan Mahasiswa. Jurnal Sport Science, 7(2). Retrieved from http://journal2.um.ac.id/index.php/sportscience/article/view/5287/2846

Afiansyah, I. Z., \& Januarto, O. B. (2018). Upaya meningkatkan keterampilan dan akurasi shooting dalam basket menggunakan metode drill pada peserta ekstrakurikuler bolabasket putra SMP. Journal of Sport Coaching and Physical Education, 2(1). Retrieved from http://journal2.um.ac.id/index.php/gpji

Afifudin, T. (2013). Survei Pembinaan Bola Basket di Klub Bintang Muda Jepara. Skripsi Tidak Diterbitkan, 1(1). Retrieved from http://lib.unnes.ac.id/18248/

Amber, V. (2016). Petunjuk Untuk Pelatih dan Pemain Bola Basket. Bandung: Pionir Jaya.

Anjasmaya, G., dkk. (2016). Pengaruh Pelatihan Speed Dribble Drill Dan Eight Types of Dribble Drill Terhadap Keterampilan Dribble Bola Basket Pada Siswa Ekstrakurikuler Bolabasket SMA Negeri 1 Seririt Tahun 2016. Jurnal Pendidikan Kepelatihan Olahraga Undiksha, 5(2). Retrieved from https://ejournal.undiksha.ac.id/index.php/JJPKO/article/view/8010

Apriansyah, F., dkk. (2018). Hubungan Koordinasi Keseimbangan Terhadap Hasil Belajar Shooting Basket Kelas VII SMP LKIA Pontianak. Jurnal Pendidikan Dan Pembelajaran, 7(3). Retrieved from http://jurnal.untan.ac.id/index.php/jpdpb/article/view/24638

Aprianto, B., \& Maidarman, M. (2019). Kontribusi Daya Ledak Otot Tungkai Dan Keseimbangan Terhadap Kemampuan Jump Shoot Atlet Putra Bolabasket OGC Padang. Jurnal JPDO, 2(1). Retrieved from http://jpdo.ppj.unp.ac.id/index.php/jpdo/article/view/187

Arif, M. R., \& Supriyadi, S. (2018). Peningkatan Kemampuan Teknik Dribble Menggunakan Metode Drill Variasi. Indonesia Performance Journal, 2(2). http://journal2.um.ac.id/index.php/jko/article/view/6701/3387

Aryana, G. (2013). Pengaruh Pelatihan Push-Up Terhadap Peningkatan Kekuatan Menarik Dan Mendorong Otot Lengan. Jurnal Ilmu Keolahragaan Undiksha, 1(1). Retrieved from https://ejournal.undiksha.ac.id/index.php/JJIK/article/view/1575/1402

Auliya S. (2018). Analisis Kemampuan Teknik Dasar Pada Atlet Bola Basket CLS KU-16 Tahun. Jurnal Prestasi Olahraga, 1(2). Retrieved from https://jurnalmahasiswa.unesa.ac.id/index.php/jurnal-prestasi olahraga/article/view/24984/22891

Auliya, S. dkk. (2019). Pengaruh Kombinasi Metode Latihan Drill dan Visual-Imagery Terhadap Keterampilan Shooting Bolabasket. Journal of Sport Coaching and Physical Education, 4(2). Retrieved from https://journal.unnes.ac.id/sju/index.php/jscpe

Azhar, M. \& Indriati, A. . (2018). Pendidikan Jasmani dan Kesehatan. Jakarta: Erlangga.

Aziz, A. (2016). Faktor Fisik Dan Teknik Pada Kemampuan Dribble Atlet Ekstrakurikuler Bola Basket Putra Tingkat SMA. Jurnal Pendidikan Kepelatihan Olahraga, 1(6). Retrieved from http://journal.student.uny.ac.id/ojs/ojs/index.php/pko/article/download/4414/4085 
Bambang, A. \& Lukmanul, H. . (2015). Pendidikan Jasman, Olahraga, dan kesehatan Kelas IX SMP/MTS. Jakarta: Pusat Kurikulum dan Perbukuan, Balitbang, Kemendikbud.

Baqiyudin, G. (2013). Perbandingan Metode Pembelajaran Whole Practice Dan Practice Terhadap Hasil Belajar Dribbling Bolabasket (Studi Pada Siswa Kelas VII SMPN 1 Jogoroto Jombang). Jurnal Pendidikan Olahraga Dan Kesehatan, 1(1). Retrieved from https://jurnalmahasiswa.unesa.ac.id/index.php/jurnalpendidikan-jasmani/article/view/2837/5750

Budianti F. Y., dkk. (2018). Pengembangan Latihan Pass-Shoot Bola Basket Melalui Media Audio Visual Pada Klub Bola Basket Gosweet Gondanglegi Malang. Jurnal Sport Science, 7(1). Retrieved from http://journal2.um.ac.id/index.php/sport-science/article/view/5280/2839

Devita, A. 2013. (2013). Survey Tes Tingkat Kemampuan Teknik Dasar Bermain Bola Basket (Passing, Dribbling, dan shooting) Pada Tim Bola Basket Putra Kelompok 18 Tahun Klub Sahabat Semarang Tahun 2012. Skripsi Tidak Diterbitkan, 1(1). Retrieved from http://lib.unnes.ac.id/18991/

Erfani, A. R. (2017). Penerapan Metode Resiprokal Terhadap Hasil Belajar Dribble Bola Basket (Studi Pada Siswa Kelas X SMK Negeri 12 Surabaya). Jurnal Pendidikan Olahraga Dan Kesehatan, 5(1). Retrieved from jasmani/article/view/19991/18293 https://jurnalmahasiswa.unesa.ac.id/index.php/jurnal-pendidikan-

Harsono. (2015). Kepelatihan Olahraga Teori dan Metodologi. Bandung: PT Remaja Rosdakarya.

Hermanto, T. (2017). Pengaruh Latihan Shooting BEEF Terhadap Gerak Dasar Shooting Dalam Permainan Bolabasket (Penelitian Eksperimen Pada Program Ekstrakurikuler di SDN Ketib Kecamatan Sumedang Utara Kabupaten Sumedang). Skripsi Tidak Diterbitkan, 1(1). Retrieved from http://repository.upi.edu/24591/

Hidayat, S. (2014). Pelatihan Olahraga teori dan metodologi. Yogyakarta: Graha Ilmu.

Khoeron, N. (2017). Buku Pintar Basket. Jakarta: Anugrah.

Khoirina, A. (2017). Peningkatan Kemampuan Daya Ledak Otot Lengan Akibat Latihan Lempar Bola Posisi Berdiri Dan Duduk Untuk Siswa Ekstrakurikuler SMA 1 Turen. SKRIPSI Jurusan Pendidikan Jasmani Dan Kesehatan -Fakultas Ilmu Keolahragaan UM., 1(1), 1. Retrieved from http://karyailmiah.um.ac.id/index.php/Penjaskes/article/view/61043

Kusuma, D. W. C. W. (2018). Pengaruh Model Latihan Run Rinjani Terhadap Hasil Under Basket Shoot Pada Tim Bola Basket Putra IKIP Mataram. JISIP (Jurnal Ilmu Sosial Dan Pendidikan), 2(3). Retrieved from http://ejournal.mandalanursa.org/index.php/JISIP/article/view/505

Langga, Z. A., \& Supriyadi, S. (2017). Pengaruh Model Latihan Menggunakan Metode Praktis Distribusi Terhadap Keterampilan Dribble Anggota Ekstrakurikuler Bolabasket Smpn 18 Malang. Indonesian $\begin{array}{llll}\text { Performance } \quad \text { Journal, } & 1(1) . & \text { Retrieved } & \text { from }\end{array}$ http://journal2.um.ac.id/index.php/jko/article/view/911/536

Majid, W., \& Roesdiyanto, R. (2018). Meningkatkan Kemampuan Teknik Dasar Shooting Bolabasket Menggunakan Metode Drill. Indonesia Performance Journal, 2(2). Retrieved from http://journal2.um.ac.id/index.php/jko/article/view/6708/3391

Nirwandi, F. U. (2016). Tinjauan Keterampilan Teknik Dasar Klub Bolabasket Putra Sekolah Menengah Atas Pembangunan Laboratorium Universitas Negeri Padang. Jurnal Mensana, 1(2). Retrieved from http://menssana.ppj.unp.ac.id/index.php/jm/article/view/52

Nuswantoro, B., \& Supriyadi, M. (2019). Meningkatkan Kemampuan Passing Bolabasket Menggunakan Permainan Pada Siswa Sekolah Menengah Pertama. Indonesia Performance Journal, 3(1). Retrieved from http://journal2.um.ac.id/index.php/jko/article/viewFile/10086/4569

Raharjo, I. dkk. (2018). Pengaruh Model Latihan Menembak Terhadap Kemampuan Jump Shoot Siswa Ekstrakurikuler Bolabasket SMA Negeri 1 Tumpang Kabupaten Malang. Jurnal Sport Science, 6(1). Retrieved from http://journal2.um.ac.id/index.php/sport-science/article/view/5259/2820

Ramadhan, B. (2017). Penerapan Latihan Part Terhadap Hasil Dribble Bola Basket Siswa Putra Kelas VII Dan VIII Yang Mengikuti Ekstrakurikuler Bola Basket Di SMP Negeri 1 Beji, Kabupaten Pasuruan. Jurnal Pendidikan Olahraga Dan Kesehatan, 5(2). Retrieved from https://jurnalmahasiswa.unesa.ac.id/index.php/jurnal-pendidikan-jasmani/article/view/21256

Risyal, F. (2018). Pengaruh Penerapan Metode Pembelajaran Tutor Sebaya Terhadap Hasil Belajar Chest Pass Bola Basket. Jurnal Pendidikan Olahraga Dan Kesehatan, 6(2). Retrieved from https://jurnalmahasiswa.unesa.ac.id/index.php/jurnal-pendidikan-

jasmani/article/view/24647/22561 
Roji. \& Yulianti, E. (2014). Pendidikan Jasmani, Olahraga dan Kesehatan kelas VIII SMP/MTS. Jakarta: Pusat Kurikulum dan Perbukuan, Balitbang, Kemendikbud.

Rustanto, H. (2016). Hubungan Antara Tinggi Badan Dan Kelincahan Tubuh Terhadap Hasil Dribble Bola Pada Permainan Bolabasket. Jurnal Pendidikan Olahraga, 4(2). Retrieved from https://journal.ikippgriptk.ac.id/index.php/olahraga/article/view/83/81

Rusyda, D. M., Nurrochmah, S., \& Heynoek, F. P. (2016). Perbedaan Pengaruh Latihan Lempar Bolabasket Terhadap Peningkatan Kemampuan Daya Ledak Otot Lengan. Jurnal Pendidikan Olahraga Dan Kesehatan, 6(2). Retrieved from http://journal.um.ac.id/index.php/pendidikanjasmani/article/view/7509/3429\#

Santoso, G. (2013). Ilmu Kesehatan Olahraga. Bandung: PT Remaja Rosdakarya.

Sari, N. L. C. M., dkk. (2019). Penggaruh Latian Four Corner Drill Dan Five Player Star Drill Terhadap Peningkatan Keterampilan Passing (Chest Pass) Pada Siswa Ekstrakurikuler Bolabasket SMP Negeri 2 Singaraja Tahun 2017. Jurnal Pendidikan Kepelatihan Olahraga Undiksha, 10(2). Retrieved from https://jurnalmahasiswa.unesa.ac.id/index.php/jurnal-pendidikan-jasmani/article/view/8167/8370

Sartini, W. O. S,. \& Rusli, M. (2019). Meningkatkan Hasil Belajar Shooting Permainan Bolabasket Melalui Penerapan Metode Drill. Jurnal Pendidikan Jasmani, 1(1). Retrieved from http://ojs.uho.ac.id/index.php/Penjaskesrek/article/view/9207/6532

Setya, C. (2014). Penerapan Model Pembelajaran Drill and Practice Terhadap Hasil Belajar Chest Pass Pada Permainan Bola Basket (Studi Pada Siswa Kelas X SMA Negeri 1 Mojokerto). Jurnal Pendidikan Olahraga Dan Kesehatan, 2(1). Retrieved from https://jurnalmahasiswa.unesa.ac.id/index.php/jurnalpendidikan-jasmani/article/view/8167/8370

Sriwahyuni, A. (2014). Pengaruh Permainan Kecil Terhadap Hasil Belajar Gerak Dasar Dribble Bolabasket (Studi Pada Peserta Didik Kelas VII Di SMP Negeri 1 Jatirogo Tuban). Jurnal Pendidikan Olahraga Dan Kesehatan, 2(2). Retrieved from https://jurnalmahasiswa.unesa.ac.id/index.php/jurnal-pendidikanjasmani/article/view/9955/9749

Subhan, M. (2013). Penerapan Pendekatan Contextual Teaching and Learning (CTL) Terhadap Hasil Belajar Dribble Bola Basket (Studi Pada Siswa Kelas VII A SMP IT Babussalam Probolinggo). Jurnal Pendidikan Olahraga Dan Kesehatan, 1(3). Retrieved from https://jurnalmahasiswa.unesa.ac.id/index.php/jurnalpendidikan-jasmani/article/view/4710/6994

Sumaryoto \& Nopembri, S. (2017). Pendidikan Jasmani, Olahraga, dan kesehatan Kelas XI SMA/SMK/MA/MK. Jakarta: Pusat Kurikulum dan Perbukuan, Balitbang, Kemendikbud.

Sya'bani, C.R., \& Nurrochmah, S. (2020). Pengaruh Latihan S-Run Dan Z-Run Terhadap Peningkatan Kemampuan Kelincahan Peserta Putra Ekstrakurikuler Bolabasket. Jurnal Gelanggang Pendidikan Jasmani Indonesia, 3(2). Retrieved from http://journal2.um.ac.id/index.php/gpji/article/view/11683

Utomo, M. (2016). Pengaruh pemberian reward terhadap hasil belajar shooting bola basket (studi pada kelas SMA Negeri 1 soko). Jurnal Pendidikan Olahraga Dan Kesehatan, 3((2)). Retrieved from https://jurnalmahasiswa.unesa.ac.id/index.php/jurnal-pendidikan-jasmani/article/view/13719

Wiarto, G. (2015). Inovasi Pembelajaran dalam Pendidikan Jasmani. Yogyakarta: Laksitas.

Wicaksono, P. (2014). Kontribusi Konsentrasi Terhadap Hasil Shooting Under basket (Studi Pada Atlet Putra Klub Bolabasket Guardian Tuban). Jurnal Kesehatan Olahraga, 2(1). Retrieved from https://jurnalmahasiswa.unesa.ac.id/index.php/jurnal-kesehatan-olahraga/article/view/6401

Wiguna, I. B. (2017). Teori dan Aplikasi Latihan Kondisi Fisik. Depok: PT Raja Grafindo.

Wiradihardja, S. \& S. (2017). Pendidikan Jasmani, Olahraga, dan kesehatan Kelas X SMA/SMK/MA/MK. Jakarta: Pusat Kurikulum dan Perbukuan, Balitbang, Kemendikbud.

Yolis, Y. A. D. (2018). Basket Untuk Pemula (Teori dan Praktik). Yogyakarta: Deepublish.

Yulidasari, R., dkk. (2016). Variasi Latihan Teknik Shooting Bolabasket Siswa Ekstrakurikuler di SMPN 22 Malang. Jurnal Pendidikan Jasmani, 25(1). Retrieved from http://training.um.ac.id/ojs/index.php/pendidikan-jasmani/article/view/4884/1282\#

Yusuf, R. J. S., \& Wibowo, R. (2017). Model Dribble Bolabasket Untuk Pemula. Jurnal Pendidikan Jasmani Dan Olahraga, 2(2). Retrieved from https://ejournal.upi.edu/index.php/penjas/article/view/09-02$05 / 5153$ 